\title{
STUDENT'S CONCEPT OF TECHNOLOGY AND BASIC COGNITION OF HISTORY OF TECHNOLOGY
}

\author{
Jiř́ KROPÁČ - Martin HAVELKA - Čestmír SERAFÍN
}

\begin{abstract}
One of the teacher's basic tasks in technical subjects is to create a student's objective concept of technology supported by balanced arguments for and against technical solutions. The paper focuses on the importance of history of technology cognition in order to create the student's concept of technology which is a part of his concept of the world. Lack of future teachers' knowledge of history of technology is also mentioned.
\end{abstract}

Key words: technical education, concept of the world, concept of technology, history of technology.

\section{ŽÁKŮV OBRAZ TECHNIKY A ZÁKLADNÍ POZNÁNÍ DĚJIN TECHNIKY}

Resumé: K úkolům učitele technických předmětů patří vytvářet žákův objektivní obraz techniky, podporovaný vyváženými argumenty pro i proti technickým řešením. Stat' je zaměřena na význam poznání dějin techniky pro vytváření žákova obrazu techniky, který je součástí jeho obrazu světa. Konstatovány jsou nedostatky ve vědomostech budoucích učitelů technických předmětů $\mathrm{v}$ dějinách techniky.

Klíčová slova: technická výchova, obraz světa, obraz techniky, dějiny techniky.

\section{1 Úvod}

Záměrem technické výchovy je rozvíjení technického myšlení a vychovanosti. Existuje shoda, že $\mathrm{v}$ př́padě technických předmětů vyučovaných na nižších stupních škol jde o zprostředkování základního porozumění technice, vytváření vyvážených postojů $\mathrm{k}$ technice, rozvíjení dovedností, kompetencí a dalších dispozic potřebných pro řešení situací spojených s využitím techniky. Jde ovšem o situace, jež lze oprávněně očekávat $\mathrm{v}$ budoucím životě žáků a jejichž řešení bude spojeno s problémy, bude tedy nejednoznačné, obtížné. $\mathrm{K}$ tomu patří také potřeba spoluvytvářet postoje žáků ke světu, postoje související s technikou.

Zabýváme-li se technickým myšlením ve smyslu vymezeném E. Franusem (1) a s tím související výchovou $\mathrm{v}$ technických předmětech, je potřeba si povšimnout postojů $\mathrm{k}$ technice jako celku, stability těchto postojů a možných způsobů vytváření těchto stabilních postojù. Jde o tzv. obraz techniky, který má ve svém myšlení zahrnut každý jednotlivec a jenž je součástí obrazu světa. Názvem obraz světa lze označit názor jedince na svět jako celek, který „,se značnou stabilitou“ předurčuje základní orientaci a základní postoje jedince. Pro obraz techniky platí totéž, jen úžeji ve vztahu k technice. Obraz techniky je tedy $\mathrm{v}$ tomto smyslu možno považovat za organickou součást obrazu světa.
Obdobně se lze setkat $\mathrm{s}$ vymezením pojmu fyzikální obraz světa $\mathrm{v}$ publikacích zaměřených na didaktiku fyziky, viz (2, s. 44).

Ve stati se budeme zabývat obrazem techniky a významem základního poznání dějin techniky pro jeho vytváŕení.

\section{Obraz techniky}

Pojmem obraz světa (Weltbild) se v souvislosti s technickým vzděláváním zabýval H. Wolffgramm (3). Obraz světa chápal jako projev uceleného souboru poznatků jedince ve vztahu k objektivní realitě. Obraz světa jednotlivce se tedy opírá o poznání objektivní reality, k tomu ve škole každý vyučovací předmět prrispívá svým dílem. Obraz světa se významně opírá o zkušenosti a prožitky individua (konstruktivismus) a je podle $\mathrm{H}$. Wolffgramma tvořen třemi souvisejícími oblastmi.

Tři oblasti a př́spěvek výuky o technice $\mathrm{k}$ nim jsou:

1. Podstata dané oblasti skutečnosti, její základní elementy a systémy, jejich struktura a hierarchické uspořádání, základní procesy a zákonitosti.

$\mathrm{V}$ prrípadě techniky se jedná o podstatu techniky, technologií, jejich specifika, základní technické elementy, systémy a jejich hierarchii.

2. Původ, vznik a vývoj oblasti, př́slušné „hnací síly“ a zákonitosti. 
Vznik a význam techniky ve vývoji lidské společnosti, zákonitosti jejího vývoje, místo a role techniky v historii a současnosti.

3. Vztahy mezi člověkem, společností a př́slušnou oblastí skutečnosti, její význam, hodnoty a smysl pro život člověka a společnosti.

Vztahy člověk - technika, způsob utváŕení techniky, odpovědnost tvưrců při vývoji techniky a uživatelů při jejím užití.

Zatímco oblasti uvedené pod označením 1. a 3. lze dosti dobře realizovat výukou zaměřenou na soudobou techniku a technologie, potom oblast ozn. 2, důležitou pro stabilní postoje $\mathrm{k}$ technice, pro uvědomění si významu techniky pro společnost $\mathrm{i}$ jednotlivce a to v pozitivním i negativním smyslu, nelze realizovat bez ohlédnutí se do minulosti. Vývoj poslání techniky a technologií v minulosti zde slouží jako ilustrace a argument a nabízí řadu pozitivních i negativních př́kladů.

\section{Vytváření žákova obrazu techniky}

Otázky vytváření žákova obrazu techniky jakožto součásti jeho obrazu světa mají vliv na výběr obsahu výuky i na proces její realizace. $\mathrm{V}$ technické výchově či $\mathrm{v}$ obecně technickém vzdělávání je důležité docenění těchto okruhů, viz (3), a jejich začlenění do výuky jako samostatného obsahu, nebo jako aspektu jiného obsahu. Jsou to tyto rámcové okruhy:

- smysl technického pokroku,

- souvislosti rozvoje techniky, individua a společnosti,

- vliv stavu vývoje techniky na společnost,

- docenění rostoucí odpovědnosti společnosti i individua za humánní způsob užívání techniky,

- možnosti řešení globálních problémů z technického hlediska (využití zdrojů materiálů, zajištění potřeb energie, zajištění potravin, ochrana prostředí).

I zde je historický aspekt, schopnost pohlédnout zpět do historie techniky obsažen. Nejsou potřebné znalosti detailní, spíš znalosti trendů, přibližných časových etap rozvoje významných oblastí techniky a zejména souvislostí s potřebami společnosti i jednotlivce, znalosti o nezbytných předpokladech a důsledcích či významu rozvoje.

Historický aspekt techniky zejména ve vztahu $\mathrm{k}$ významu techniky pro společnost považujeme za základní princip výuky o technice (uplatnění vztahu účel - prostředek). Také nezbytná zdrženlivost a obezřetnost při činnosti s technikou, jež je dnes všeobecně požadována, může být, jak již naznačeno, právě dějinami techniky ve výuce „doložena“.

Problematikou dějin techniky $\mathrm{v}$ technické výchově se proto zabýval mj. V. Soták (4), zpracován byl studijní text (5). Otázkám zastoupení otázek vývoje techniky ve výuce na nižších školách je věnována pozornost mj. i v SRN (6).

\section{$4 \mathrm{~K}$ začlenění dějin techniky do přípravy učitelů technické a informační výchovy}

Studijní předmět dějiny techniky byl tradičně zařazován do př́ípravy učitelů technické výchovy, podle našich zkušeností se $\mathrm{s}$ oblibou $\mathrm{k}$ jeho výuce hlásili zejména věkově starší učitelé VŠ. Problém nastal, když př́prava učitelů technické výchovy byla obohacena $\mathrm{o}$ informační část $\mathrm{v}$ daném časovém prostoru prímé výuky. Doprovázeno to bylo nutnou a pochopitelnou redukcí rozsahu výuky některých „klasických“ studijních předmětů. $\mathrm{Na}$ druhé straně možnosti informačních technologií umožňují začlenit řadu obsahových celků, mj. právě týkajících se tzv. širších souvislostí techniky (ekonomické, ekologické, historické, estetické aj.), do textů umístěných na www stránkách pracoviště. Tato cesta se jevila jako optimální a nebyla již tehdy nová.

Než padlo rozhodnutí výuku dějin techniky výrazně redukovat nebo i zrušit, provedli jsme v našich podmínkách formou ,akčního výzkumu“ zjištění znalostí či spíš představ studentů 2. ročníku o základních souvislostech $\mathrm{z}$ dějin techniky. Výsledky byly neuspokojivé. Zde budeme prezentovat jen dotazy, bez vyhodnocení úspěšnosti:

Liší se člověk od zvířete tím, že „používá nástroje“, nebo že si „nástroje vyrábí“? letopočtem?

Byl bronz používán $\mathrm{v}$ období před naším

Byly železné kovy používány $\mathrm{v}$ období před naším letopočtem?

Lze železný kov vyrobit z rudy, aniž by byla ruda roztavena?

Byl hrnčířský kruh používán již ve středověku?

Lze vyrobit ploché sklo jinak než válcováním?

Odhadněte, kdy člověk dokázal použivat „k dopravě“ kolo?

Kdo je považován za vynálezce knihtisku a kdy k vynálezu došlo? 
kola?

Byla ve středověku používána vodní

Dále následují otázky na skutečnosti, které jsou uvedeny na www stránkách pracoviště, odpovědi nebyly lepší:

Kdy přibližně a odkud přijel první vlak do Olomouce?

Byl za první republiky používán plynový sporák, elektrický bojler, kovová okna, plastová okna, byly stavěny domy s rovnou střechou?

Jmenuje se firma Sigma po Sigmundovi?

Co firma Sigma především vyráběla?

Byly za první republiky používány popelnice, vodovod i na vesnici?

Na základě dotazování, při němž ne „noví“ studenti jevili slabé znalosti základních údajů z dějin techniky i v prŕípadech, že jsou podklady umístěny na stránkách katedry, jsme došli k závěru, že dějiny techniky je třeba začlenit do povinné výuky. Neznají-li nejzákladnější fakta, těžko mohou usuzovat na význam techniky a obraz techniky by nebyl úplný a zdůvodněný u studentů samotných a v budoucnu ani u jejich žáků. V souladu s (7, s. 52-86) doceňujeme strukturu fakt, pojmů a generalizací ve vzájemné souvislosti či podmíněnosti těchto tří kategorií. Pro ilustraci - stěží si lze představit bez základních znalostí plné pochopení názoru prezentovaného M. Raabem (8, s. 28), že středověk překonal ,zdánlivě kulturnějšíi“ a bohatší starověké civilizace rozšířením technických a technologických znalostí.

Dnes je tedy předmět Dějiny techniky vyučován jako povinný (1 hod cvičení, 3. roč., LS). Tím je tedy zajištěno i využití této výuky pro vytváření adekvátního obrazu techniky $\mathrm{u}$ budoucích učitelů technická výchovy.

\section{Závěr}

Koncepty obraz světa a obraz techniky jakožto jeho organickou součást považujeme za vhodné pro vymezení celkového postoje ke světu a k technice, který předurčuje jednání individua. Kromě vlastní zkušenosti se situacemi spojenými s technikou působí na vytvoření obrazu techniky zkušenost zprostředkovaná učitelem ve výuce. Zde jsou nezbytné nejen jisté znalosti, ale i schopnost interpretace a uvědomění si souvislostí. V současných podmínkách je přímá výuka dějin techniky v přípravě učitelů technické a informační výchovy potřebná.

\section{Literatura}

[1] FRANUS, E. The Dual Nature of Technical Thinking. In Technology as a challenge for school curricula. The Stockholm Library of Curriculum Studies. Stockholm: Institut of Education Press, 2003, s. 141-144. ISSN 14034972. ISBN 91-7656-543-2.

[2] FENCLOVÁ, J. Úvod do teorie a metodologie didaktiky fyziky. Praha: Stát. pedag. nakl., 1982. ISBN nemá.

[3] WOLFFGRAMM, H. Zur Weltbildfunktion allgemeiner technischer Bildung (Ein Beitrag zur multifunktionalen Techniksicht). Technica Didactica, 1999, Jahrgang 3, Band 1, S. 3-24. ISSN 0949-8109.

[4] SOTÁK, V. Význam dejín techniky v technickej výchove. In MEDACTA 99. Zborník 2b. Nitra: SLOVDIDAC, 1999, s. 114 118. ISBN 80-967746-4-6.

[5] DLUHOŠ, J. a VALA, M. Vybrané kapitoly z dějin techniky. Ostrava: Ostravská univerzita, 1996. ISBN 80-7042-112-6.

[6] Bildungsstandards im Fach Technik für den mittleren Schulabschluss. Düsseldorf: VDI Verein Deutscher Ingenieure e. V., 2004. ISBN nemá.

[7] PASCH, M. aj. Od vzdělávacího programu k vyučovací hodině. Praha: Portál, 1998. ISBN 80-7178-127-4.

[8] RAAB, M. Materiály a člověk. Praha: Encyklopedický dům, 1999. ISBN 80-86044-130 .

Příspěvek vznikl za podpory projektu FRVŠ č. 1800/2012, „Inovace přípravy učitelů techniky orientovaných disciplín v oblasti experimentální práce".

Doc. Ing. Čestmír Serafín Dr.

Doc. PaedDr. Jiří Kropáč CSc.,

Mgr. Martin Havelka Ph.D.

Katedra technické a informační výchovy, Pedagogická fakulta UP

Žižkovo nám. 5

77140 Olomouc, ČR

Tel: +420 585635 802, +420 585635805 , +420585635 812

E-mail: cestmir.serafin@upol.cz, jiri.kropac@upol.cz,martin.havelka@upol.cz Www pracoviště: www.kteiv.upol.cz 